\title{
Hybrid
}

Revue des arts et médiations humaines

$4 \mid 2017$

Malaise dans la représentation

\section{The contagion of images: embedded voices and sensory apparatuses in an Amerindian shamanic ritual}

Andrea-Luz Gutierrez Choquevilca

\section{(2) OpenEdition \\ Journals}

Electronic version

URL: https://journals.openedition.org/hybrid/807

DOI: 10.4000/hybrid.807

ISSN: 2276-3538

This article is a translation of:

La contagion des images : voix enchâssées et dispositifs sensoriels dans un rituel chamanique amérindien - URL : https://journals.openedition.org/hybrid/799 [fr]

Publisher

Presses universitaires de Vincennes

\section{Electronic reference}

Andrea-Luz Gutierrez Choquevilca, "The contagion of images: embedded voices and sensory apparatuses in an Amerindian shamanic ritual", Hybrid [Online], 4 | 2017, Online since 04 September 2017, connection on 13 April 2022. URL: http://journals.openedition.org/hybrid/807 ; DOI: https:// doi.org/10.4000/hybrid.807

This text was automatically generated on 13 April 2022.

Revue Hybrid 


\title{
The contagion of images: embedded voices and sensory apparatuses in an Amerindian shamanic ritual
}

\author{
Andrea-Luz Gutierrez Choquevilca
}

\section{Introduction}

1 This article questions one of the main issues of shamanic ritual enunciation, based on an Amazonian example: the composition-translation process that the ritual expert has to go through in order to "represent" the invisibles during his performance, and the sensory apparatuses involved. What are the linguistic, gestural and sensory means used by the yachak shaman in order to make up for the lack of visibility of the beings summoned as part of ritual performances? How do notions as abstract and hard to circumscribe as those of "spirit," "demon" or "soul" find an echo in the most private experience of Amerindian peoples? One way of dealing with this issue has proved to be particularly fruitful in the field of anthropology. ${ }^{2}$ This method consists in using ethnographic materials to question the cognitive, discursive or sensory means used in the ritual performances to depict these entities and communicate on or with them. The attention shifts from the description of a particular world view to the empirical apparatuses involved in the "creation of these worlds," the ways of worldmaking to quote an expression dear to Nelson Goodman. ${ }^{3}$ These apparatuses do not so much reveal "fossilized" knowledge as they constitute cultural performances, somewhat comparable with those exerted in what we are used to calling "works of art" in the Western world. ${ }^{4}$ Far from widening the gap between the artistic and ritual performances strictly speaking, the anthropology of shamanism emphasizes on the contrary the common points between the mechanisms of image unveiling and image concealing, because they are based on a fundamental human aptitude: communication.

2 The ritual image is here to be understood as the medium of a perceptive (visual, sound, olfactory, etc.) and cognitive comprehension: in this case, one would gladly say a 
mental image. This results in the attribution of a shifted subjectivity by the ritual expert who manipulates this mental image: from his point of view, referring to the taruan grass snake is a way to introduce the spirit to the audience as the therapeutic act is performed, even though this might be partially unintelligible to the people kneeling around the sick person. One of the consequences of this common belief is that a successful therapeutic ritual is a ritual in which images are the object of a contagion among participants: the patient imagines, sees, feels, perceives "something" that he has trouble putting into words. These images are then deciphered in various ways by the ritual participants, thereby falling within a special form of communication. It is the motives of these acts of communication that interest us here.

Based on a critical feedback on the notion of acting image and that of "effectiveness of symbols" dear to Lévi-Strauss, we will examine the perceptive and cognitive conditions of involvement in the Amerindian ritual. This line of analysis is based on a detailed ethnography of the shamanic rituals of the Runa societies from the Peruvian Amazon ${ }^{5}$ and on a pragmatic analysis of the ritual participants' discursive systems of figuration. What happens when the objective of the ritual consists in the pure and simple obviation of the rules of traditional communication? The peculiarity of the shamanic ritual lies in the fact that the specialist seems to be the only one possessing the key to the lexical games and sensory apparatuses that he establishes. The audience, whether they are patients or neophytes are all bewildered. The Western paradigm of communication, as defined by language sciences around the notion of signifying intention and relevance, is here subverted in favor of a performance based on the multiplication of voices, perspectives and possible interpretations of the image. The ethnography of the therapeutic ritual allows us to examine the hypothesis that, in this context, it is precisely the deficient nature of the sign - the transgression of the rules of traditional communication and partial dimension of deciphering - that gives the image all its power.

\section{The efficient image: Guillermo Haya and Muu-Igala's Way}

The ethnographies focusing on the systems of thought and shamanic beliefs reveal that the Amerindian traditions are equally oral and "iconographic." The study of the Amazonian ritual experts' songs brings out a series of images, the scenography of which - sung, seen, or felt - makes an act of figuration coincide with a therapeutic act, namely an act of transformation of the living, the body and matter. "With my powerful ikara songs, we can bring back littles souls. My ikara songs heal and kill. Can't you hear them whistling over your head, when I am healing?" asked me a Runa shaman named YanaShunku, "black liver." It is hard not to see an explicit reference to the fact that the sound dimension of his performance surpasses its visuals, a few sibylline sentences whispered between two puffs of smoke on a silent body. We are here talking about the acting image. Besides the performative dimension of the discourse, it is important to note the close link between the utterance of these songs, and performances drawing on other categories of knowledge and perceptive experiences: the transmissions of breath, the tobacco smoke, the sound of the shaman's voice turning into a whistling or into music, the rustling of the leaves rattle brushing the skin of the sick person lying on the mat... Which categories of visibility does the Amerindian shaman, the one called yachak, 
"he who knows" in the Quechua language, resort to in order to summon beings during the ritual: spirits, demons, animals or hybrid entities? How can we explain the singular effectiveness of ritual poetry?

Let us focus on Claude Lévi-Straus's text of reference, in order to further study this issue, a text written by someone who has dramatically fallen into oblivion. This author is a Cuna Amerindian named Guillermo Haya, who in the late 1940s, captured a song sung by a shaman from his village in Panama to a parturient woman, during her difficult delivery: "Muu-Igala's Way." This indigenous text is rare for its time. It was transcribed by the author in his own Cuna language and translated into Spanish, it was then sent to Swedish ethnographer Erland Nordenskiöld and eventually published after the death of the latter by his successors Nils M. Holmer and Henry Wassen in Göteborg in 1947. The enthusiasm of Lévi-Strauss as he read this song led him to write an article entitled "The effectiveness of symbols" in 1949, which would later become a chapter of his Structural Anthropology (1958). This seminal and controversial article proposes a new exegesis of the Cuna shamanic words, seen through the prism of "performance." It is driven by a desire to understand what takes place when this song is uttered in the shaman's lively words, in the middle of the ritual. Claude Lévi-Strauss breaks down the term-to-term analogy between the Amerindian parturient woman's aching body and the images evoked by the shaman's words. Here, he affirms "the song constitutes a psychological manipulation of the sick organ, and it is precisely from this manipulation that a cure is expected." Immersed in Haya's story, from which he derives the ethnographic material, Lévi-Strauss notes the fluctuation between mythical and physiological themes. The belief emerges "as if to suppress the distinction between them and make it impossible for the sick woman's mind to distinguish their respective characteristics." The Cuna shaman calls for his guardian spirits, represented by sculpted wooden statuettes called nuchu:

The (sick) woman lies in the hammock in front of you.

Her white tissue lies in her lap,

Her white tissues move softly.

The (sick) woman's body lies weak.

When they light up (along) Muu's way, it runs over with exudations and like blood.

(v. 84-90).8

6 In "Muu-Igala's [dark] way," bloodied by the difficult delivery, the ritual gloss reveals the "magical clothes," which will help the nuchu guardian spirits identify the sick woman's body, in order to cure her. Remarkably, none of the organs or present entities, be it the patient, the shaman, or the protective spirits, areexplicitly or unequivocally named. On the contrary, everything takes place as if all direct reference to objects and the body should be given up in favor of multiple, evanescent and incomplete images, since polysemy and semantic shift are prevailing. The parturient woman's vagina is thus called "Muu-Igala's way," the pains embodied by monsters or by "animals increasing the pains of the woman giving birth," according to Guillermo Haya. It is:

Uncle Alligator Tiikwalele, with glistening body, who moves his glistening flippers, whose flippers conquer the place, push everything aside, drag everything; Nele $\mathrm{Ki}(\mathrm{k})$ kirpanalele, the Octopus, whose sticky tentacles are alternately opening and closing; and many others besides: He-who-has-a-hat-that-is-soft, He-who-has-ared-colored-hat, He-who-has-a-variegated-hat, etc; and the guardian animals: the black tiger, the red animal, the two-colored animal, the dust-colored animal; each is tied with an iron chain, the tongue hanging down, the tongue hanging out, saliva 
dripping, saliva foaming, with flourishing tail, the claws coming out and tearing things 'all like blood, all red' ( 253-298). ${ }^{9}$

7 A formidable stage of embodied pains, like Hieronymus Bosch's depiction of hell, the song delivers a continuous flow of images that seem to have no equivalent outside the realm of myth, images which the parturient woman sees as they are introduced into the "place" of her own corporeal experience. What are the tools available to anthropology in order to examine this contagion of images among participants during the shamanic ritual? Lévi-Strauss maintains, in his famous text on the "effectiveness" of rituals, that the question one should answer is the following: can one express the inexpressible? How do the novice and "uninitiated" patient manage to fit in a communication apparatus that largely transcends them, to the extent that their belief is based on a fragile set of improbable signs? The adherence to the ritual and creation of a common ground ${ }^{10}$ for experts, uninitiated and invisibles is indeed contemporary with the production of plethora of hints, icons and signs - often an image linked with speech - that contribute to reducing the opacity of the performance and establishing the cognitive and sensory conditions of a sharing. "The shaman, Lévi-Strauss explains, provides the sick woman with a language, by means of which unexpressed, and otherwise inexpressible, psychic states can be immediately expressed."11

Lévi-Strauss's interpretation of the Amerindian ritual specialist's formulation of these "possible worlds" was largely criticized, and especially his symbolic interpretation. ${ }^{12}$ These reactions both emphasize the inherent interest of the selected object and the analytical difficulty the ethnographer is confronted with. Where Lévi-Strauss thought he spotted a fortunate connection with psychoanalysis in this dialectic between the image of myth and that of bodies, ${ }^{13}$ the reader alas finds no element allowing for an understanding, in the time and place of the ritual itself, of the contagion of such beliefs among the ritual participants. The symbolic explanation is confronted with the fact that virtually all of the words uttered by the shaman remain irreducibly and frequently abstruse and hardly intelligible for the novice, that the ritual action is largely nonverbal, that it is mediated in loci verbi by objects... Actually, why is a "special" discursive practice implemented here, which is formalized through specific enunciative constraints: parallelism, abstruse metaphors, lists of spirit names, so many traditional rhetoric techniques that are widespread in the field of literature? ${ }^{14}$

9 The difficulty to carry out the ethnography of such an apparatus lies in its nature: this apparatus cannot be reduced to language communication, although the latter is a prerequisite for the former. The apparatus emerges in the gestures of and bodily relations between the ritual participants, in the substances that are circulated, the visions of the initiated expressed in words, confided to the invisibles. There is a genuine translation process involved here, operated at the three levels noted by Jakobson: intralinguistic, interlinguistic and intersemiotic, and embracing the contours of the discordant and conniving relations between language, senses and thoughts. ${ }^{15}$ There is no need to radically oppose the approach adopted by Lévi-Strauss and the approach consisting in accounting for a pragmatics of ritual acts of communication. Actually, this opposition seems trite nowadays, inasmuch as the issue is radically different. In fact, Lévi-Strauss himself acutely sensed the difficulty to link the issue of performance with that of the formal dimension of ritual action and the singular type of communication involved. Aware that the ritual action cannot be reduced to the uttered words, and even less to the way it is scripted by the myth, he initiated an innovative line of research in the last pages of Mythologiques, pointing out that it would be more 
productive to refrain from looking at "what these ritual words say, and focus on how they say it." 16 The analysis of the ritual action involves something different from the theory of reference, which is based on the necessary relation between the sign and the object it indicates in the world. ${ }^{17}$ It is indeed a pragmatics that accounts for the intentions concealed behind the words and gestures, for the background knowledge and for the underlying meanings of any action, which are the driving forces of humans and their invisible partners.

\section{The indeterminacy of reference or ritual enigma}

What does the contemporary ethnography of Amerindian peoples teach us about the effectiveness of ritual images? Let us get back to the biography of a quite singular person, shaman yachak "he who knows," and shed light on his function of maker of visibility and occultation on the ritual stage. Among the Quechua people of the Amazon, the title of ritual expert is the crowning achievement of a long and difficult initiation consisting in experiencing a ritual death (sasina) and the dissolution of the shaman's body upon contact with his initiating spirits. Transfixed by hunger - the result of a drastic fasting -, the applicant is subjected to the ordeal of visions, for all of the ikara songs, which define his ability to cure people, are bestowed upon him by oneiric entities, by animals or spirits met in his dreams. The main issue of his initiation is to memorize therapeutic songs. This memorizing technique is unique in that it is described by novices as essentially resulting from a non-verbal, bodily experience: a sensory experience induced by the ingestion of unusual or toxic substances (plant beverages, larvae, insects, pebbles) and the transformation of his voice in an attempt at imitating animals: the screaming piha, the pecari or aquatic spirits. ${ }^{18}$ These elements serve as so many sensitive clues substantiating the relations that the initiated person has established with the invisible entities, of which he becomes the only custodian and spokesperson in the eyes of the uninitiated ones. The accounts represent the shaman's body as a fanciful one, full of hematophagous wiruti darts, removed one by one from the master's body throughout the shaman's initiation. 


\section{Kay wiruti kallu kallu shina rikurin, ninchi « shun» chasna rikunayu kapayan. Kasha kasha kasha apillapas : kasna wiña' wiña' tukun.}

\section{Chupashpan surkushkani amun shiminmanta, rikuchihuni : chayta yachakunchi llawsawa supay wirutiwapas.}

11 From a cognitive perspective, such link between semantic memory and memory of an autobiographical type is fundamental, because it embeds the performance of the healing act into an older experience which, in the expert's opinion, coincides with a diversion of the traditional function with which language and perception are ascribed. Communicating via more or less unintelligible sound icons, feeding beings or objects that are both inside and outside - these little "ancestors" or secondary spirits called supaywiruti -, constitute skills acquired over time, which confirm the shaman's feeling of uncanny experienced in the privacy of his own body.

However, while the discourse on the initiation seems to minimize the oral channel, it nonetheless reveals a paradox. This paradox lies in the close relation between the healing power and the ability to master the ritual enunciation techniques, which themselves systematically occur through oral performances, more specifically through songs. The shamanic ikara song repertoires represent an ancient tradition for the Runa people from Peruvian Upper Amazon, a common tradition in the vast Northwest Amazon region. The healing power entirely depends on the "breath" of the voice rather than on other techniques, such as the use of material medica, an essential part of the initiation that is yet hardly effective when it comes to extracting the evils from the body of black magic victims. This therapeutic breath is named with the verbal root puku - characterized by polysemy: it refers both to the hunter's "blow" as he shoots a curare-coated dart at an arboreal prey, and to the shaman who "blows" an ikara "song" into the patient's or cursed person's body to cure them, a body made porous by tobacco and smoke. In other words, curing amounts to "blowing" or bursting into songs designed as supaywiruti (darts of the spirits) "projectiles" stored in the shaman's body. In the manner of learned diplomats, the runa shamans move to territories far away from their native region, so as to pass on their ikara songs to neighbor peoples: the 
Jivaro people - Achuar, Aguaruna, the Shipibo-speaking peoples (Pano linguistic family). The circulation of these songs is ensured by stable expressions characterized by a combination of strict syntactic rules (parallelism, a singular epistemic marking, the erotesis technique or in other words rhetorical questions), together with significant variations and lexical innovations: each of these peoples borrows new syntactic units from languages spoken by their neighbors (yora that means "body" in the Shipibo language is thus transposed into certain Quechua repertoires), while certain incantation masters innovate by creating "nouns" or a specific referential code to label new categories of spirits. Each name refers to a sensitive description (sound, visual, tactile, etc.), the manifest content of which is delivered during a muskuchi vision. In this way, the sisyawayttiii onomatopoeia - the lexicalization of a sound icon of a non-human voice - has become in the Peruvian Upper-Pastaza region the standard term to refer to the Anaconda spirit during the therapeutic ritual, while the ophidian is named amarun in the language of the uninitiated people. The spirit of the egret is named by metonymy, by referring to an "ashen-gray clothing item" uchpakamisayu, and the pink river dolphins of the tropical rivers, powerful aquatic chimeras, are named after the color red, complemented by an ideophone describing the sound made by the appearance of the spirit on the water surface: puka-waytii. ${ }^{19}$

14 These substitution and oblique naming games are legion in the Amerindian shamanic repertoires, so much so that it is often maintained that the exercise of the twisted language ${ }^{20}$ would be one of the most important foundations of the shamanic and ritual discourse.

How can one explain this distortion of the relation between the sign and the object or mental image that it denotes? A first assessment consists in observing that in the context of the nursing of the sick person, the ordinary communication modes are simply deprived of their traditional function observed in the everyday use of language. Actually, the maxims of communication introduced in the philosophy of language and in pragmatics by Herbert Paul Grice - now considered as pivotal in the practice of human communication -, such as the cooperation principle, the maxims of quantity (the principle of economy that implies that the uttered information must be necessary), of quality (a principle based on the speaker's sincerity), of relevance (which implies that the information is both sufficient and relevant, so that a message is properly conveyed $)^{21}$ are here subverted in favor of a performance based on a few constant and seemingly "absurd" formal traits, to quote terms used by Holmer and Wassen, showing their stupefaction at the reading of Muu-Igala's way. Among these traits are repetition, catachresis, an immoderate use of periphrasis, strategies of denomination based on analogy or metonymy, the use of stripped-down syntactic rules, the implementation of variable lists of nouns in a constant parallelistic order... These formal characteristics have been examined in most Amerindian shamanic repertoires, from the Suya societies in central Brazil to the Warao and Piaroa from Venezuela, or more recently among the Pano-speaking Sharanahua and Marubo peoples, so much so that they can be considered as invariants showing a relatively stable form of constraint of Amerindian ritual enunciation. ${ }^{22}$

This song sung by a yachak shaman of the Quechua people from the Peruvian Amazon provides us with a blueprint. Rather than "communicating" a message, it introduces the following enigma - "Is it the spirit roaming?" supaychu - the expression of which 
makes us think, through a mise en abyme, that it could be endlessly declined, thus summarizing the tragedy of representation:

$\begin{array}{ll}1 & \begin{array}{l}\text { Sumpra-punta puri-k supay-chu } \\ \text { Sumpra-uku puri-k supay-chu } \\ \text { Sumpra-washa purik supay-chu }\end{array} \\ & \text { Wayra-punta purik supaychu } \\ & \text { Wayra-uku purik supaychu } \\ & \text { Wayra-washa purik supaychu } \\ & \text { Tamya-punta purik supaychu } \\ \text { tamya-uku purik supaychu } & \text { tamya-washa purik supaychu } \\ & \text { Chawpi tuta-p' purik supaychu } \\ & \text { Yaku-awa purik supaychu (...) } \\ & \text { Purma-uku purik supaychu (...) } \\ & \text { Kaspi-siki-pi tiyak supaychu (...) } \\ \text { Mishushillu-siki-pi shayak supaychu } & \end{array}$

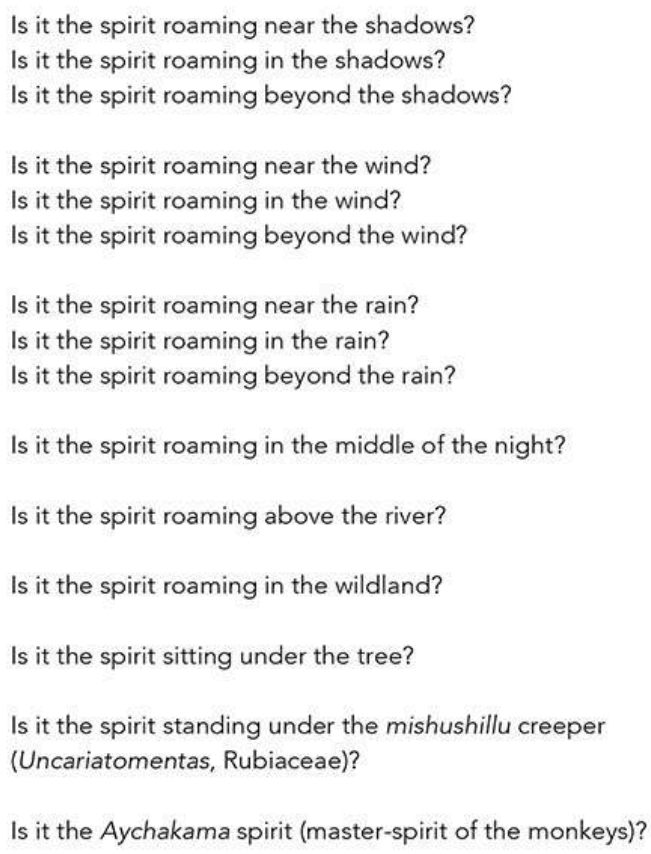

Rather than identifying a singular being or a place of capture of the sick person's soul, the ritual words initiate a gradual process of subjectification, from a series of topological clues drawing a kind of mental map. ${ }^{23}$ The yachak starts a quest expressed by metonymies listing the passageways, the habitat of pathogenic spirits where lies the reflection, the captured soul of the patient. In this way, the diagnosis coincides with the therapy. On the one hand, the yachak must identify the supay spirit who is responsible for the bewitchment, through a series of questions. On the other hand, the multiplication of sensitive images describing his spatial progression simultaneously gives the key to the cure. This rhetorical use of questions and metonymy allows the specialist to shift the attention of individuals toward the neighboring areas where the ritual action is performed. The attention is diverted from the shaman and patient, to focus on the localization of the spirit who is responsible for the sickness, an unstable and depersonalized space, that of illness: shadow, wind, rain, night, river, wildland, creeper... A landscape associated with disease materializes around the evocation of the name. From a formal perspective, the parallelistic structure provides this quest with a medium, a quest consisting of (changing) place names declined in a constant syntactic form, particularly easy to remember:

\begin{tabular}{|c|c|c|c|}
\hline List of nouns & Locative suffix & $\begin{array}{l}\text { Predicate }+ \\
\text { Agentive }\end{array}$ & $\begin{array}{l}\text { Modality: Rhetorical } \\
\text { question }\end{array}$ \\
\hline $\begin{array}{l}\text { Shadows } \\
\text { Wind } \\
\text { Rain }\end{array}$ & $\begin{array}{l}\text { /-punta/ } \\
\text { At the end, } \\
\text { frontier }\end{array}$ & $\begin{array}{l}\text { /puri-k/ } \\
\text { to walk, to roam- } \\
\text { AG }\end{array}$ & $\begin{array}{l}\text { Supay-chu } \\
\text { Spirit-INTER } \\
\text { Is it the spirit? }\end{array}$ \\
\hline Night & & /tiya-k/ & \\
\hline Wildland & & to be seated-AG & \\
\hline Tree & & /shaya-k/ & \\
\hline
\end{tabular}




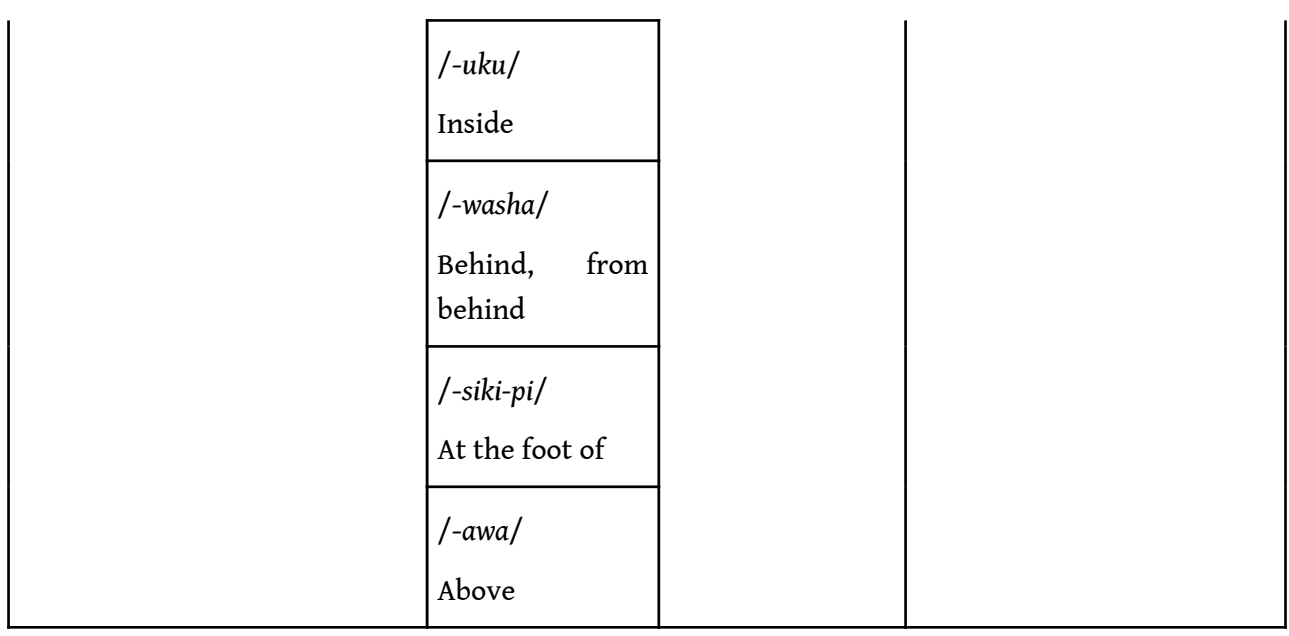

In the meandering of this stream of images, the impossibility to express ex abrupto the name of the summoned spirit constitutes the basis of the ritual performance. This name only appears in the epilogue, in v. 15, with the secret formula "Aychakama" (unknown to non-shamans and reserved for the ritual language), directly addressed to the invisible interlocutor, referring to the master of monkey-spirits: that which hunts humans, just like humans hunt game in the woods, by driving a sting into their flesh. The tension building up around the formulation of the name is also obvious in the performance of a shaman from the Warao-Winikina people living in the valley of the Orinoco River delta in Venezuela, as studied by ethnomusicologist Dale Olsen. These repetitive words uttered in a monotonous voice by the hoarotu shaman come down to the quest for the name of a hebu animal-spirit responsible for a childhood disease: ${ }^{24}$

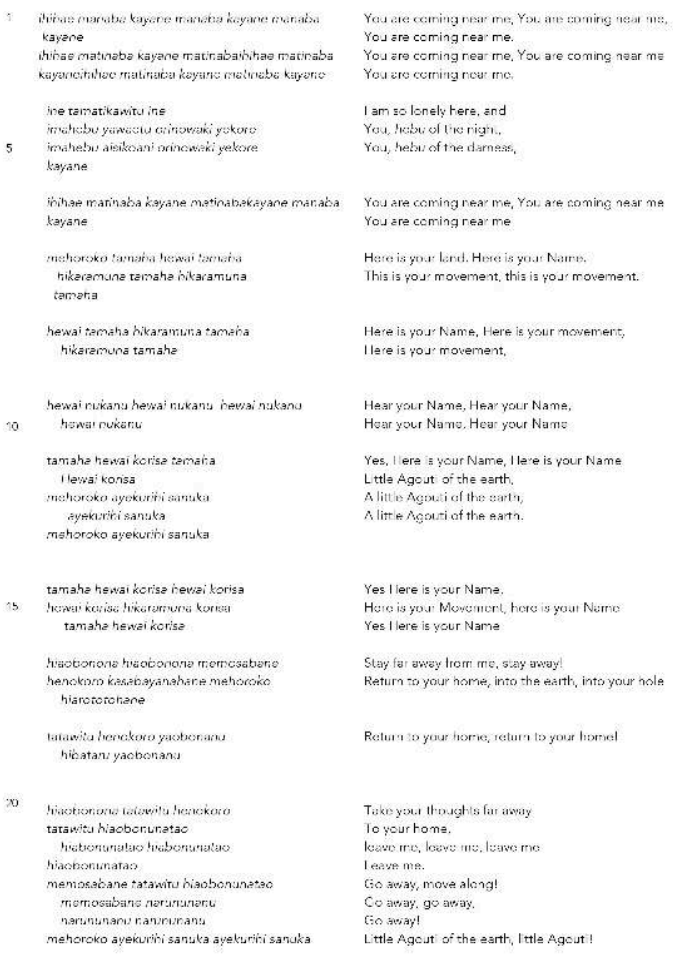


19 Although the utterance draws a mental map in the previous song, here it embraces the contours and "movement" of the beings it characterizes in the song "little agouti of the earth". ${ }^{25}$ It also gives the imagination the only "visible" trace of a dialogue initiated by the shaman, in which the patient and recipient spirit become mixed up as they listen together: "Hear your name" represents the root of the evil hebu, and then ends with the shaman urging the spirit to leave: "Stay far away from me! (...) Take your thoughts far away (...) Leave me!" (v. 16, v. 19, v. 22). However, while there is a beginning and end to the evocation, which are clearly identifiable in the utterance (the expulsion) and audible by default (silence), they only serve to better determine the origin of the disturbance: the possibility of endlessly extending the descriptions of these pathogenic beings.

In the Quechua repertoire, although the utterance of a name tends to be problematic, it is replaced by a multiplicity of sensitive qualities as the only possible way to represent the entities escaping the principles of the relation of denotation, which is inherent to ordinary language. A Quechua shaman thus offers a range of mental images, a kaleidoscope of colors worn by the spirit of a snake responsible for the capture of a feverish patient's soul, resulting from a sorcery-related aggression:

$\begin{array}{ll}1 & \text { Uchpa uchpa tarunaka tarunay } \\ \text { Uchpa uchpa tarunay taruna taruna } \\ \text { Imapitay wawaynipa animantaka? } \\ \text { apapashpa payka sirihushpan ukupishi } \\ \text { apashkaylla apashkalla } \\ \text { Uchpa uchpa tarunay tarunay } \\ \text { Uchpa uchpa tarunay tarunay } \\ \text { Killu killu tarunayka taruna tarunay } \\ \text { Killu killu tarunay tarunay tarunay } \\ \text { Inchichipi tarunayka tarunay tarunay } \\ \text { Killu killu tarunay tarunay } \\ \text { Maypi sirin chay ukupichu wawaynipa } \\ \text { animanta pitichishpa? } \\ \text { tarunay tarunay tarunay } \\ \\ \text { Killu killu tarunayka tarunay } \\ \text { Killu killu tarunay tarunay tarunay } \\ \text { Kaspi awapi siririk tarunayka tarunay } \\ \text { Sirihu' ukupichu yaykuchishpa wawaynipa } \\ \text { animantaka } \\ \text { Siririshpa tarunayka tarunay tarunay } \\ \text { 20 } \\ \text { Puka puka tarunay tarunay (...) } \\ \text { Tarunay tarunay tarunay }\end{array}$

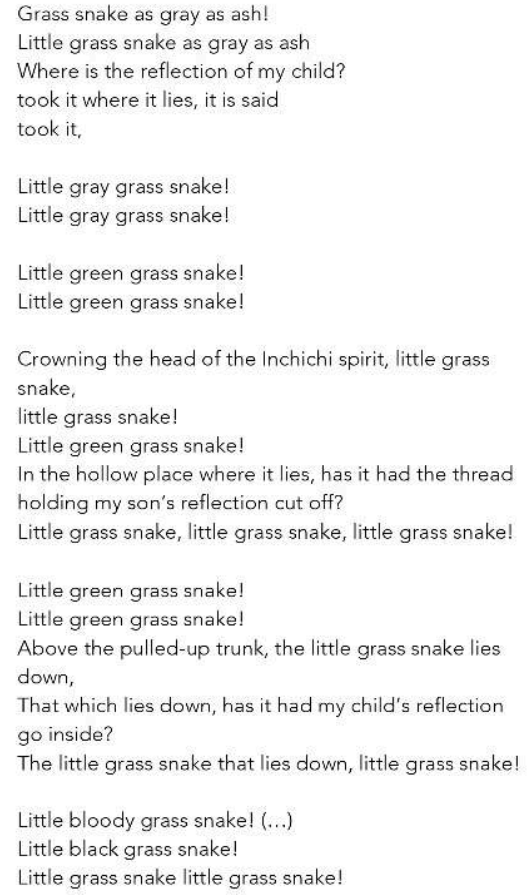

Instead of delivering an established diagnosis, a clear-cut image, or a proper noun allowing for the individualization of the referent of the discourse, the ritual gloss evokes - through a range of colors (ashen gray, green, blood-red, black) - perceptive clues providing a multi-faceted outline of the invoked beings' visual appearance. These evocations are interrupted by rhetorical questions, a technique that is typical of erotesis. These questions focus on the place where the "soul-reflection" was captured, which from the shaman's perspective represents the position of a "child."

v. 3 Where is the reflection of my child?

v. 12 In the hollow place where it lies, has it had the thread holding my son's

reflection cut off? 
v. 17 By lying down, has it made my child's reflection enter inside?

a quest diffracted in the utterance. This narrative element is common to numerous Quechua and Warao repertoires. ${ }^{26}$ Admittedly, one could resign oneself to the idea that there is actually nothing to convey. Or, one could examine the assumption that these colors are not evoked accidentally. I suggest that by default, they characterize a possible mode of representation of the entities that are brought together. In fact, the utterance does not refer to a singular and unique being, ${ }^{27}$ nor does it aim to give information according to the rules of ordinary communication: relevance, economy of syntactic units, compliance with the conventions of dialogue... In this case, the sensory qualities are uttered out loud, so that the patient engages in introspection, in the deciphering of the visible form of the spirits that have put a spell on him. The deficient nature of the sign and the sibylline characteristic of the conveyed message provide a medium. Admittedly, such highly speculative exercise stands out from the initial intuition based on the physical invisibility (to the patient's eyes) of the entities summoned in the ritual space. However, this outline of chromatic figuration is based on common implicit knowledge on the "possible world" inherent to the summoned spirits, acquired by hearsay during the collective learning of myths. The expressed images interact with the thread of the myth to form a palimpsest. The assumption is that these beings - only visible to the shaman - are equipped with visible ornaments, such as the colorful reptile's dress, that they can appear in an anthropomorphic or zoomorphic form, that their sensitive qualities are indicative of their power, that they are capable of transforming, etc. The song is the expression of these underlying mental images. ${ }^{28}$

The evocative power inherent to ritual words is also increased by material and technical apparatuses. Actually, the musicality of the voice waving down one octave with each repetition of the same verse, goes together with highly suggestive gestures. Achiote powder, an Amazonian vermilion tinctorial plant, almost the same color as "the blood-red grass snake" responsible for the bewitchment, is laid down before the patient, while the female healer brushes the sick person's body with a yellow cotton flower in order to remove or "sweep" pichana the pain and fever away, symptoms that the ikara songs hardly ever explicitly mention. In other words, through an extraordinary economy of linguistic and gestural means, the shaman is able to suggest rather than explicitly state the identity of new players on the ritual stage. However, the gist of the message does not lie in the definition of an identity. What is here involved is rather indeterminacy, what Quine would call the inscrutability of the reference, in language philosophy. ${ }^{29}$ In a sense, these ikara songs mean nothing. Or more precisely, they do not say that there is nothing, but that nothing can be stated, except in a form and apparatus that escape the communication model based on the transparency of meaning.

\section{Variations and embedded voices}

Let us now get back to the therapeutic situation itself. There is nothing spectacular in the ritual scene among the Runa people from the Peruvian Amazon. What is involved here is a gradual and imperceptible participation of each and every one in a play. Every participant plays with the others, without ever becoming completely aware of the meaning of the event occurring here and now. It is in this indistinct yet highly 
suggestive context that the fertile ground of the adherence to the ritual is laid down. My friend Yana Shunku, a runa shaman from the Peruvian Amazon, is crouching above a sick man lying on the grid made out of palm bark. Tonight, he is working in complete darkness, palpating the body in several places: he stops in the soft part of the neck, gently strokes the forehead, weighs up the hands, palpates the stomach, the liver. He is looking for an answer in the sick man's hands: sweat, heat or shiver, palpitations... The pulse is an infallible sign, he tells me that he can hear it like a quivering voice expressing pain with sounds only he can hear "tsiiktsiiktsiik." In fact, he and his patient, since it is the main symptom described by the latter to the specialist. The sick man is a fifty years old skilled hunter, who apparently fell prey to a spirit while at the lagoon, a few hours walk from the village. As he arrives, he whispers these words:

Umaynikamuyurin, lismayashpapurini, yanah'llarikuni, tsiktsiikruran

I feel light-headed, I feel dizzy when I walk, all I see is black, it goes tsiiktsiik

(stretching his arm and feeling his pulse).

The shaman does not seem to pay much more attention to him. He seems to be miles away, rolls his cigar in the palm of his hands and blows gently on it. Then, he turns to the sick man's son, crouching a few meters away. Muskushkankichu? ("Have you had a dream?"). His interlocutor, Nemesio, remains impassive. A few minutes pass. An outside observer would only hear the bark floor creaking under the weight of the crouching and lying bodies. The shaman continues to palpate the sick man's aching body. Finally, Nemesio speaks:

Kaynawashasachachawpimantashamushpayni...

Yanasumbriruyuatunrukuumayushichasnallatata... Imasnaram?

A few days ago, as I came back from the lands in the middle of the forest... They say

that with its black hat on, he has a huge head, it's exactly that... What can it possibly be?

The shaman listens attentively, and in his turn keeps quiet. Not much else is said. Sitting cross-legged, Yana Shunku whispers inaudible words, the palm of his hand folded into a tube over his cigar, placed in front of his mouth. His murmurs are interspersed with short exhalations, followed by a slower one, which seems to conclude a long incomprehensible and hard-to-pronounce sentence. His diction is extremely fast and monotonous. Later on, he confirms that the spirit of the black ray Raya Supay is the one who has shot an invisible dart into the hunter's body, weakened by his long walk back to the village. The symptoms of the sick man are confusion, dizziness, chronic fever (a feeling of oppressive heat in the chest), a vague feeling of sadness and dejection. What are the words used to describe such aches? The sick man complains about a singular sadness when he affirms that he is literally dying:

Ayaawwawayni, llakipatawañuhunimi

Aaah my son... I am really dying of melancholy.

The shaman engages in a fight. He is going to shoot his own supaywiruti "arrows" 30 - a term used to refer to the helping spirits who fight against the spirits responsible for the bewitchment. However, if one sticks to what is clearly stated, heard and seen, the outside observer - the ethnographer and uninitiated patient share an analogous condition - has to recognize that the evidence of these entities' presence is extremely rare, if any. The first stage here is that of the calling. As he starts the cure, the yachak engages in a captatio benevolentiae: he summons his assistant spirits by means of a direct vocative address, naming them his own "ancestors," thus establishing a direct relation of filiation with the latter, who is made out of the same flesh, in a way. At the same 
time, he slowly blows his cigar smoke and takes a few sips of eau-de-vie from a calabash, before he delivers an incantation, transcribed as follows:

\begin{tabular}{|c|c|c|}
\hline \multirow[t]{4}{*}{1} & $\begin{array}{l}\text { Ayawaska tukuy awiluyni shamunkichi! } \\
\text { ñukas rikuni }\end{array}$ & $\begin{array}{l}\text { O all my ancestors, those of the ayahuasca, } \\
\text { come to me! }\end{array}$ \\
\hline & Tukuy awiluyni shamunkichi! & I too, can see \\
\hline & Yakumanta sachamanta & O all my ancestors, come! \\
\hline & & From the water, from the woods... \\
\hline \multirow[t]{2}{*}{5} & Yachayninkuna yarkaahun & My helping spirits are hungry! \\
\hline & Ahaaa "salud»! & Ahaaa "cheers"! \\
\hline \multirow{5}{*}{10} & Kunkaymanta mariri & From the throat, the mariri song comes out, \\
\hline & Kunkayma & From the throat, \\
\hline & Shamuy kamalunka ñukarayku! & Please Kamalunka come for me! \\
\hline & Kamalunka suma' ishkay wayusitayu kanki & Graceful kamalunka who possesses two small \\
\hline & kamalunka & wayusa plants (Ilexsp.) \\
\hline \multirow[b]{4}{*}{15} & shamuy shamuy kamalunka & Please come kamalunka! \\
\hline & Shamuy shamuy tukuy awiluyni & Come $\mathrm{O}$ all my little ancestors! \\
\hline & $\begin{array}{l}\text { Tukuy tukuy shamunkichu kaypimi } \\
\text { kamalunka? }\end{array}$ & $\begin{array}{l}\text { Are all of you arriving here together } \\
\text { kamalunka? }\end{array}$ \\
\hline & Sapallaynistu kani kamalunka! & I am still alone kamalunka! \\
\hline & Kumpanyaway shamuy kamalunka! & Please come with me kamalunka! \\
\hline \multirow[t]{4}{*}{20} & Warmistumi kanki kamalunka? & Are you a real little woman? \\
\hline & Kamalunka ñukashina, kani warmi Kamalunka & $\begin{array}{l}\text { Kamalunka like myself, I am the } \\
\text { kamalunka woman! }\end{array}$ \\
\hline & .... Kamalunkay mariri & .... Mariri O kamalunka \\
\hline & (...) Wueltarimunki kamalunka! & (...) You make your way kamalunka! \\
\hline
\end{tabular}

28 A horde of spirits enters the stage: the spirits of plants ingested during the shamanic initiation, the famous psychotropic beverage called ayahuasca ${ }^{31}$ or the Strychnos sp.kamalunka seed, ingested during his apprenticeship. These helping spirits are known for lodging themselves into a phlegmatic substance, commonly referred to as mariri, a "song, phlegm" which is supposed to be uttered or expectorated during the cure. The shaman calls his spirits "ancestors" awilu, or supayninkuna "my spirits," the term supay ambivalently indicating both demons and helping entities. The shamans' "implicit mythology," derived from the stories told during the initiation, identifies these spirits with stings contained in their own body. This body is seen as a blowpipe - literally a pukuna blowpipe. ${ }^{32}$

However, the shaman's entrance shows a starving and thirsty being, like the entities he summons and soon feeds with tobacco and alcohol. The frontier between these bodies is thus partly abolished during the ritual. Actually, when the shaman drinks a strong alcoholic beverage, the spirits feed via his body. The process of condensation of the ritual metabolism in the person of the specialist is noteworthy. It is basically the very condition of the ritual participants' potential adherence to the cure. At the end of the initiation, which consists in ingesting mostly toxic and painful substances, the shaman comes to swallowing and putting foreign bodies into his own: glowing kuru larvae, supaywiruti darts, mineral elements, if necessary. The initiation leads to a complex subjectification process, during which the beginner shaman's body, painfully weakened by reclusion, sometimes by the ingestion of psychotropic drugs, becomes the repository of new entities, players, his transformed body bearing their mark and "representing" them, both as an icon and an index - a sign of "presence." When the ritual specialist eats or drinks during the ritual performance, the action can be considered both as reflective (he feeds himself) and transitive (he feeds the spirits), as demonstrated by the 
happy cry to get inebriated "Ahaaa cheers!" (v. 6). The principle of adherence to the shamanic ritual partly relies on the acceptance of this clause. The self-referential magic words "Kamalunka similar to myself, I am the kamalunka woman!" (v. 18 KamalunkañukashinakaniKamalunka), makes the shaman's voice the embedding of a nearly-other voice, which is itself subjected to the principle of indeterminacy. It is indeed remarkable that, as he utters these words, his experience as an initiated person (to whom beings of inexpressible appearance have become "visible") and as a human therapist (a being of flesh existing here and now, in front of the patient) superimpose or condense to provide an utterly indiscernible image of his body. The comparative modal qualifier -shina "similar to," which simultaneously confirms the doubt and makes the belief possible, draws the link between the current locator and this vegetable "little woman" named kamalunka, member of a group of helping spirits who are ordered to participate in the ritual via the reciter's voice.

The context of the ritual action duplicates itself: it consists both of the shaman uttering his song and the spirits literally coming out of his mouth. This reflexivity of the ritual action is set up in favor of the development of a new deictic field that constitutes the "meta-context" of the ritual action: shamunkichukaypimi "are you arriving here?," the proximity deictic here coupled with an evidential suffix emphasizing the truth or ostension of the referent -mi, which makes one believe that this space is "here," "before one's eyes," anchored in the present experience. It is not so much the transfer of information, the principle of non-contradiction or economy of words that matters, as the setting up of this new place for interaction between participants. After he utters these words out loud, the shaman transposes them into his musical breath embracing the melodic contours of the song. What prevails is the bodily expressiveness, concentration, contemplation, musicality of the voice, the extremely codified whistling of the smoke coughed up on the ill body, which is located below and beyond the discursive field. The yachak may end his dialogue with an original protocol similar to ordinary greetings: (v. 19) "you make your way Kamalunka!."

What happens from the patient's perspective? The pain he endures finds a singular expression in the emotional field, through the descriptive and perceptive dimension they take on during the performance, as demonstrated by this chant of dementia meant to cure a lost hunter: ${ }^{33}$ 


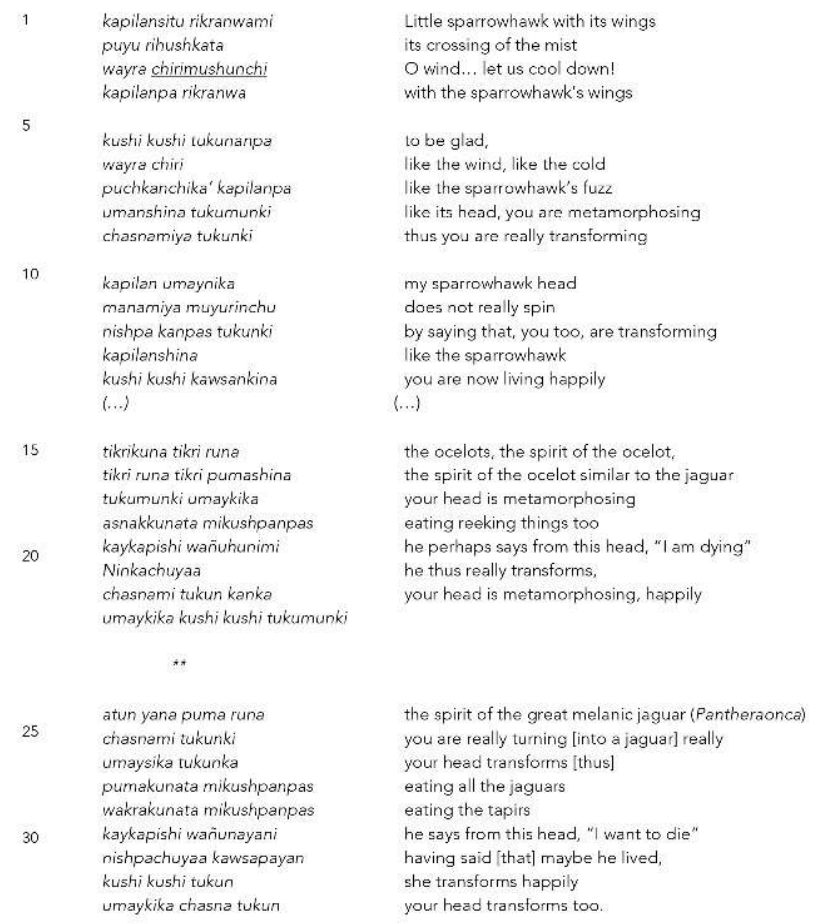

The shift in personal indicators (pronouns of the first, second and third persons) illustrates this singular dialogue, in which the possible permutation of the recipients makes the scene inextricable. As a matter fact, the speaker occupies a manifold position. He adopts the figure of the sparrowhawk, the ocelot or the jaguar, then lends his body and voice to the patient to say the healing words, the cooling down of the fever, in a constant back and forth between the first and second person: "my sparrowhawk head does not really spin" (v. 10-11), "your head is metamorphosing, happy" (v. 22). A genuine concert of embedded voices manifests itself in this chant of dementia. The contradictory emotions of the patient (joy v. 19; will to die v. 28) are mentioned as two sides of the same relation, which functions here like a switch. The logical distinction opposing emotions such as sorrow and jubilance would replace the silent distinction between suffering and healing in the sick person's experience. This distinction echoes the intimate expression of pains suffered by the dizzy old man, who previously felt, deep down in his heart, this dark "will to die" (wañu-naya-) that goes together with the disease.

To summarize, rather than solving the riddle put forth by Lévi-Strauss after he discovered Cuna Indian Guillermo Haya's song, this approach more modestly aims to open ways for pragmatic anthropology to explore, provided that the paradigm based on the deciphering of a signifying intention, the principle of relevance and the search for denotation are abandoned. I have given a portrayal of a performance in which the words, pains and ritual objects-images constitute potential translations of "possible worlds." What the Amazonian Runa shaman unveils is his apparent impossibility of explicitly representing the entities participating in the ritual scene and the paradox of the designation act that "multiplies" rather than it manages to individualize a being or a player. The presence of a multiplicity of players can indeed be inferred from the mental images introduced by these songs. The specificity of ritual images lies in their in situ condition of production, whether they are pronounced or implied by other 
semiotic modes, gesture, breath, tobacco smoke, but also in their temporal status. These images will never manage to free themselves from the acts of production or perception through which they have come to being. The shamanic performance actually provides a context in which every image indexes and above all affects a relation rather than individual terms. It is precisely the contagion of images, the fact that a same vision is shared - with all the subsequent difficulties - that will define the positions of the players, their identity or their "face," to borrow a term from Goffman's terminology. In this way, the Runa people determine that the yachak shaman's position is analogous to that of his non-human peers, when they "see" the Tsunki water spirits use a ray as an elegant headdress, a silurid fish as a belt and an anaconda as a hammock. However, the analogy is confronted with its own limits. The complicity described by the initiated people and established via the sharing of a vision is a figurative complicity: it stems from the sharing of the figuration conditions themselves, the characteristics of which are mentioned above: indeterminacy of the reference, repetition and incompleteness. The variations of the ritual image - the singing voice, the voice "blown" with the tobacco smoke, the whistling voice - constitute so many techniques that aim to submit the shaman's monologue to a dialogic form, the image to its temporal dimension: incomplete.

\section{BIBLIOGRAPHY}

BAUMAN Richard and SHERZER Joel (ed.), Explorations in the Ethnography of Speaking, Cambridge University Press, Cambridge [1974], 1989.

BLOCH Maurice, Essays on cultural transmission, Oxford, Berg Publishers, 2005.

CESARINO Pedro N., "Entre la parole et l'image. Le système mythopoétique Marubo", Journal de la Société des américanistes, vol. 97, no. 1, 2011, p. 223-257.

DÉLÉAGE Pierre, Le chant de l'anaconda. Enquête sur l'épistémologie rituelle du chamanisme sharanahua, Nanterre, Société d'ethnologie, 2009.

FONTAINE Laurent, "Les cours d'eaux dans les incantations chamaniques des indiens Yucuna (Amazonie colombienne)," Journal de la Société des américanistes, vol. 97, no. 1, 2011, p. 119-150.

FOX James J., “'Our Ancestors Spoke in Pairs': Rotinese View of Language, Dialect, and Code," in BAUMAN Richard and SHERZER Joel (dir.), Explorations in the Ethnography of Speaking [1974],

Cambridge, Cambridge University Press, 1989, p. 65-85.

GOODMAN Nelson, Ways of Worldmaking, Brighton, Harvester Press, 1978.

GRICE H. Paul, “Meaning,” Philosophical Review, no. 67, 1957, p. 377-388.

GUTIERREZ CHOQUEVILCA Andrea-Luz, "Sisyawaytiitarawaytii. Sifflements serpentins et autres voix d'esprits dans le chamanisme quechua du haut Pastaza (Amazonie péruvienne)," Journal de la Société des américanistes, vol. 97, no. 1, 2011, p. 179-222. 
HANKS William, “Comment établir un terrain d'entente dans un rituel?," Cahiers d'anthropologie sociale, vol. 5, "Paroles en actes," Carlo SEVERI and Julien BONHOMME (eds.), 2009, p. 87-115. JAKOBSON Roman, “On Linguistic Aspects of Translation,” On Translation 3, 1959, p. 232-39. KOPENAWA Davi and ALBERT Bruce, La Chute du Ciel. Paroles d'un chaman Yanomami, Paris, Plon, 2010. KRIPKE Saul, Naming and Necessity, Oxford, Blackwell, 1972.

LÉVI-STRAUSS Claude, Anthropologie structurale, Paris, Plon, 1958.

LÉVI-STRAUSS Claude, L'Homme nu, Paris, Plon, 1971.

LUNA Luis Eduardo, "Icaros: Magic Melodies Among the Mestizo Shamans of the Peruvian Amazon," E. Jean MATTESON LANGDON and Gerhard BAER (dir.), Portals of Power: Shamanism in South America, Albuquerque, University of New Mexico Press, 1992, p. 231-253.

MONOD-BECQUELIN Aurore, "Le sang et le corps, ou le blanc et le noir? Contribution à l'étude du parallélisme dans la tradition orale maya," Journal de la Société des américanistes, vol. 72, 1986, p. 7-31.

MONOD-BECQUELIN Aurore, "Le tour du monde en quelques couplets. Le parallélisme dans la tradition orale maya," in FERNÁNDEZ-VESTJ. (ed.), Kalevala et traditions orales du monde, Paris, Editions du CNRS, 1987, p. 467-488.

MONOD-BECQUELIN Aurore, "Monologues polyphoniques. Les discours rituels maya," in Nicole REVEL and Diana REY-HULMAN (eds.), Pour une anthropologie des voix, Paris, L'Harmattan/INALCO, 1993, p. 295-327.

OVERING Joana, "The Shaman as a Maker of Worlds", Man, New Series, vol. 25, no. 4, 1990, p. $602-619$

oLSEN Dale, "Magical Protection Songs of the Warao Indians," Latin American Music Review, vol. 1, no. 2,1980 , p. 131-161.

OLSEN Dale, Music of the Warao of Venezuela: Song People of the Rain Forest, Gainesville, University Press of Florida, 1996.

QUINE Willard Van Orman, Word and Object, MIT Press, Cambridge [MA], 1960.

SHERZER Joel, Kuna Ways of Speaking. An Ethnographic Perspective [1983], Tucson, Hats off Books, 2001.

SEEGER Anthony, Why Suyá Sing? A Musical Anthropology of an Amazonian People, Cambridge, Cambridge University Press, 1987.

SEVERI Carlo, Le Principe de la chimère. Une anthropologie de la mémoire, Paris, Aesthetica/Éditions Rue d'Ulm/Musée de Quai Branly, 2007.

SEVERI Carlo, "Transmutating Beings: A Proposal for an Anthropology of Thought," Hau, vol. 4, no. 2, 2014.

SEVERI Carlo and BONHOMme Julien (eds.), Cahiers d'anthropologie sociale, vol. 5, "Paroles en actes," 2009.

SHERZER Joel, Verbal Art in San Blas. Kuna Culture through its Discourse, Cambridge, Cambridge University Press, 1990.

SHERZER Joel, Kuna Ways of Speaking. An Ethnographic Perspective [1983], Tucson, Arizona Hats off Books, 2001. 
SPERBER Dan, La Contagion des idées: théorie naturaliste de la culture, Paris, Odile Jacob, 1996.

SPERBER Dan and WILSON Deirdre, La Pertinence: communication et cognition, Paris, Minuit, 1989.

TAYLOR Gérald, “ Supay,” Amerindia, no. 5, 1980, p. 47-63.

TOWNSLEY Graham, "Song Paths: the Ways and Means of Yaminahua Shamanic Knowledge”, L'Homme, no. 126-128.33, 1993, p. 449-468.

\section{NOTES}

1. The Runa people ascribe the syntactic units supay, aya and alma with a meaning that varies depending on the context. These terms can be translated as "demon" supay, "spectre, ghost" aya and "reflection, soul" alma. Their polysemy is the result of a re-semantization operation that occurred during the colonial era, when the first Spanish missionaries arrived (see Gérald Taylor, "Supay," Amerindia, no. 5, 1980, p. 47-63). These "spirits" vanish as quickly as they appear and correspond more to mental images contextually associated with an ability to affect, to act upon. The conditions of visualisation and perception of these images are subjected to often exclusive constraints (extreme fasting, sexual abstinence, cataleptic state, narcosis, solitude), to such an extent that they would justify the default qualification of "in-visible" for "spirit," which is considered as negative in the terminology familiar to anthropologists. These two notions, taken outside an ethnographic context, would essentially mean no more than a lack of visibility of the designated object in ordinary perceptive conditions, and considering them as a given or as endowed with a concrete meaning outside their ethnographic context, and especially their context of circulation, would be nonproductive.

2. It is now unthinkable to consider that the religious thinking of traditional societies is limited to narrative processes cut off from any historical context. Significant recent contributions have demonstrated that social and cultural memory unfold both in the explicit discourse and through rituals and non-verbal actions, the performance of which ensures the persistence and transmission among a given collective or cultural system (Dan Sperber, La Contagion des idées: théorie naturaliste de la culture, Paris, Odile Jacob, 1996; Maurice Bloch, Essays on cultural transmission, Oxford, Berg Publishers, 2005). A fertile application of this approach to Americanist materials is explored by Pierre Déléage, Le Chant de l'anaconda. Enquête sur l'épistémologie rituelle du chamanisme sharanahua, Nanterre, Société d'ethnologie, 2009; Carlo Severi and Julien Bonhomme (eds.), Paroles en actes, Cahiers d'anthropologie sociale, vol. 5, Paris, L'Herne, 2009; Pedro N. Cesarino, "Entre la parole et l'image. Le système mythopoétique Marubo," Journal de la Société des américanistes, vol. 97, no. 1, 2011).

3. Nelson Goodman, Ways of worldmaking, Brighton, Harvester Press, 1978.

4. A term-to-term comparison of this approach to art with the ethnography of shamanic performances was outlined by Overing from piaroa materials (Joana Overing, "The shaman as a maker of worlds," Man, New Series, vol. 25, no. 4, 1990). This article does not constitute an attempt at this kind of exercice.

5. These Quechua-speaking hunter-gatherer-clearer societies - around 4,200 individuals in 2014 occupy the alluvial valley of the Pastaza River, a northern tributary of the Amazon River in Peru. The Runas (an ethnical self-denomination referring to "human," "spirit," "people") are intermarried with the members of the Jivaro and Zaparo-Andoa group. The circumstances of their colonial ethnogenesis and multi-ethnic development can partly be explained by their mastery of inter-linguistic translation and other forms of iconic communication (Kohn, 2002; Andrea-Luz Gutierrez Choquevilca, "Sisyawaytiitarawaytii. Sifflements serpentins et autres voix 
d'esprits dans le chamanisme quechua du haut Pastaza (Amazonie péruvienne)," Journal de la Société des américanistes, vol. 97, no. 1, 2011).

6. Claude Lévi-Strauss, "The Effectiveness of Symbols," in Structural Anthropology, Basic Books Inc., New York, 1963, p. 192.

7. "First there is a description of the woman lying in her hammock or in the native obstetrical position, facing eastward, knees parted, groaning, losing her blood, the vulva dilated and moving (...). Then the shaman calls by name the spirits of intoxicating drinks; of the winds, waters, and woods; and even - precious testimony to the plasticity of the myth - the spirit of the silver steamer of the white man"' (Claude Lévi-Strauss, Structural Anthropology, Basic Books Inc., New York, 1963, p. 193).

8. Claude Lévi-Strauss, Structural Anthropology, Basic Books Inc., New York, 1963, p. 190.

9. Claude Lévi-Strauss, Structural Anthropology, Basic Books Inc., New York, 1963, p. 195.

10. This issue of the development of a "common ground" is indeed at the heart of the anthropological debate on ritual (William Hanks, "Comment établir un terrain d'entente dans un rituel?," in Carlo Severi and Julien Bonhomme (eds.), Paroles en actes, Cahiers d'anthropologie sociale, vol. 5, Paris, L'Herne, 2009.

11. Claude Lévi-Strauss, Structural Anthropology, Basic Books Inc., New York, 1963, p. 198.

12. See for example Carlo Severi, "Transmutating beings: A proposal for an anthropology of thought," Hau, vol. 4, no. 2, 2014.

13. Let us quote the structural operation of shaping of the emotions and thoughts, which Claude Lévi-Strauss regards as the basis of the effectiveness of symbols and common with psychoanalysis: "It would be a matter, either way, of stimulating an organic transformation which would consist essentially in a structural reorganization, by inducing the patient intensively to live out a myth - either received or created by him - whose structure would be, at the unconscious level, analogous to the structure whose genesis is sought on the organic level. The effectiveness of symbols would consist precisely in this "inductive property," by which formally homologous structures, built out of different materials at different levels of life organic processes, unconscious mind, rational thought - are related to one another." (Claude Lévi-Strauss, Structural Anthropology, Basic Books Inc., New York, 1963, p. 201).

14. Joel Sherzer, Verbal Art in San Blas. Kuna Culture through its Discourse, Cambridge, Cambridge University Press, 1990; Id., Kuna Ways of Speaking. An Ethnographic Perspective [1983], Hats off Books, Tucson, Arizona, 2001; Fox, James J., “'Our Ancestors Spoke in Pairs': Rotinese View of Language, Dialect, and Code," in Richard Bauman and Joël Sherzer (eds.), Explorations in the Ethnography of Speaking [1974], Cambridge, Cambridge University Press, 1989; Aurore MonodBecquelin, "Le sang et le corps, ou le blanc et le noir? Contribution à l'étude du parallélisme dans la tradition orale maya," Journal de la Société des américanistes, no. 72, Paris, 1986; Ead., "Le tour du monde en quelques couplets. Le parallélisme dans la tradition orale maya," in Jocelyne Fernández-Vest (ed.), Kalevala et traditions orales du monde, Paris, Éditions du CNRS, 1987; Ead., "Monologues polyphoniques. Les discours rituels maya," Pour une anthropologie des voix, Nicole Revel and Diana Rey-Hulman (eds.), Paris, L'Harmattan/INALCO, Paris, 1993; Joana Overing, "The shaman as a maker of worlds," Man, New Series, vol. 25, no. 4, 1990; Carlo Severi, Le Principe de la chimère. Une anthropologie de la mémoire, Paris, Aesthetica/Éditions Rue d'Ulm/Musée du Quai Branly, 2007; Pierre Déléage, Le Chant de l'anaconda. Enquête sur l'épistémologie rituelle du chamanisme sharanahua, Nanterre, Société d'ethnologie, 2009; Andrea-Luz Gutierrez Choquevilca, "Sisyawaytiitarawaytii. Sifflements serpentins et autres voix d'esprits dans le chamanisme quechua du haut Pastaza (Amazonie péruvienne)," Journal de la Société des américanistes, vol. 97, no. 1, 2011.

15. Roman Jakobson, “On linguistic aspects of translation," On Translation 3, 1959, p. 233.

16. Claude Lévi-Strauss, L'Homme nu, Paris, Plon, 1971, p. 600-601. 
17. We refer the reader to Saul Kripke's analysis of this issue outside the ritual context (Saul Kripke, Naming and Necessity, Blackwell, Oxford, 1972).

18. Andrea-Luz Gutierrez Choquevilca, "Sisyawaytiitarawaytii. Sifflements serpentins et autres voix d'esprits dans le chamanisme quechua du haut Pastaza (Amazonie péruvienne)," Journal de la Société des américanistes, vol. 97, no. 1, 2011.

19. Andrea-Luz Gutierrez Choquevilca, "Sisyawaytiitarawaytii. Sifflements serpentins et autres voix d'esprits dans le chamanisme quechua du haut Pastaza (Amazonie péruvienne)," Journal de la Société des américanistes, vol. 97, no. 1, 2011.

20. Graham Townsley, "Song paths: the ways and means of Yaminahua shamanic knowledge," L'Homme, no. 126-128.33, 1993, p. 465.

21. In particular, these maxims allow one to solve questions pertaining to the linguistic determination of utterances. When one or more maxim(s) is (are) violated, the interlocutor is led to formulate hypotheses and interpretations beyond what is explicitly stated by the utterance, by tracing back the speaker's communicational intention. Actually, many pieces of information are implicit and cannot be deduced from the logical meaning of the utterances. These hypotheses, also called "implicatures" in Grice's pragmatic analysis, assimilate human communication with an inferential process of deciphering rather than with a code model (Dan Sperber et Deirdre Wilson, La Pertinence: communication et cognition, Paris, Minuit, 1989).

22. Anthony Seeger, Why Suyá Sing? A Musical Anthropology of an Amazonian People, Cambridge, Cambridge University Press, 1987; Dale Olsen, Music of the Warao of Venezuela: Song People of the Rain Forest, Gainesville, University Press of Florida, 1996; Joana Overing, "The shaman as a maker of worlds," Man, New Series, vol. 25, no. 4, 1990; Pierre Déléage, Le Chant de l'anaconda. Enquête sur l'épistémologie rituelle du chamanisme sharanahua, Nanterre, Société d'ethnologie, 2009; Pedro N. Cesarino, "Entre la parole et l'image. Le système mythopoétique Marubo," Journal de la Société des américanistes, vol. 97, no. 1, 2011).

23. This technique is widespread, namely in the ritual Yucuna and Marubo songs (Laurent Fontaine, "Les cours d'eaux dans les incantations chamaniques des indiens Yucuna (Amazonie colombienne)," Journal de la Société des américanistes, vol. 97, no. 1, 2011; Pedro N. Cesarino, "Entre la parole et l'image. Le système mythopoétique Marubo," Journal de la Société des américanistes, vol. 97, no. 1, 2011, p. 223-257).

24. Dale Olsen, "Magical Protection Songs of the Warao Indians," Latin American Music Review, vol. 1, no. 2), 1980, p. 135-136.

25. It is the same oblique naming strategy that prevails here, like in every other repertoire: the ritual term dedicated to the invoked entity "little Agouti of the earth" ayekurihi is different from its name in the everyday Warao language: kahamuru in the Winikina language or kuhuamare in the Wayo language for the species Dasyproctaaguti (Dale Olsen, "Magical Protection Songs of the Warao Indians," Latin American Music Review, vol. 1, no. 2, 1980, p. 136). The ethnomusicologist collected over twenty songs dedicated to various hebu animal spirits (iguana, tortoise, anaconda, tapir, jaguar, young stag, opossum, ant-eater, etc.), with a strictly analogous composition at the grammatical and narrative levels: description of the place, movement, name, and expulsion of the entities.

26. See Andrea-Luz Gutierrez Choquevilca, "Sisyawaytiitarawaytii. Sifflements serpentins et autres voix d'esprits dans le chamanisme quechua du haut Pastaza (Amazonie péruvienne)," Journal de la Société des américanistes, vol. 97, no. 1, 2011; Dale Olsen, "Magical Protection Songs of the Warao Indians," Latin American Music Review, vol. 1, no. 2, 1980; Id., Music of the Warao of Venezuela: Song People of the Rain Forest, Gainesville, University Press of Florida, 1996.

27. Only one proper noun is involved in this almost exclusively sensitive evocation, that of Inchichi, renowned master of game in the Runa mythology, since the spirit of the snake is his known helping spirit. 
28. The autobiographical testimony of Davi Kopenawa, Yanomami shaman and leader, achieving the vision of the spirits of the xapiri forest, confirms this assumption: the xapiri are understood as endless refractions of images: the mirrors, light and ornamentation of the xapiri are most often mentioned (Davi Kopenawa and Bruce Albert, La Chute du Ciel. Paroles d'un chaman Yanomami, Paris, Plon, 2010, p. 99). Everything that has to do with spirits is ornamented, bright and devoid of substance: their paths, the mirrors through which they move, the floors and roofs of their homes, the clearings that they landscape in the forest. All of these are pure images that continuously refract one another. The songs themselves constitute "images," the specificity of which is to take root in the mind. "The words of the xapiri are always taking a new form and cannot be forgotten [...] they expand and successively take root inside of you, thus, we need not draw them to remember them. Their paper is our mind, and since very ancient times, this mind has become as long as an endless book." (Davi Kopenawa and Bruce Albert, La Chute du Ciel. Paroles d'un chaman Yanomami, Paris, Plon, 2010 p. 554).

29. This hypothesis derives from a thought experiment called "radical translation," i.e. the translation of the word "Gavagai" to a foreign language speaker. This thought experiment demonstrates that the same statement from a radically foreign language can be translated in several ways. It must be noted that in this way, we get several translations that are mutually incompatible, although they are correct translations into foreign languages. Based on this thought experiment, the theory of inscrutability (or indeterminacy) of the reference prevents two speakers of different languages from understanding each other. It seems indeed that one never really understands what a foreign language speaker means and that eventually one can never grasp what they are talking about. Linguistic relativity would be immanent (Willard Van Orman Quine, Word and Object, MIT Press, Cambridge [MA], 1960.)

30. These stings, called wiruti in the Quechua language, occupy a liminal position between interiority and exteriority, since they come from the shaman's stomach, body or throat, from which they are expelled by means of specific breathing techniques; consequently, they are considered as coming from the patient's body: this sick body, victim of a sorcery-related aggression, has been "penetrated" (yaykushka) by the pathogenic agent that has lodged itself into it.

31. Among others: Banisteriopsiscaapi, Psychotria Viridis and many other adjuvants (see for example Luis Eduardo Luna, "Icaros: Magic melodies among the Mestizo shamans of the Peruvian Amazon," in E. Jean Matteson Langdon and Gerhard Baer (eds.), Portals of Power: Shamanism in South America, Albuquerque, University of New Mexico Press, 1992).

32. The shaman's bodily techniques refer to a framework that is common to most groups from the northwest Amazon: the framework of ingestion and extraction. The shaman sucks the darts materialisation of the cause of the illness - from the patient's body.

33. Part of this song was removed so as to lighten the analysis. It consists of a list detailing the appearance and movement of each spirit-animal responsible for the bewitchment: horned screamer, bald vulture, tapir etc.

\section{ABSTRACTS}

This article takes an Amazonian example to question one of the main issues of the shamanic ritual utterance: the operation of composition-translation that the ritual specialist has to carry out to "represent" the invisibles during his performance, and the sensory apparatuses it implies. 
In fact, the study of the ikara therapeutic songs of the Runa people from the Peruvian Amazon (Upper Pastaza) and the context in which they are uttered by the yachak shaman reveals the enigmatic dimension of the ritual gesture: the duplicity of the sign, evanescent presence or secret evocation, a mental image that persists and spreads among the participants. What are the linguistic, gestural or sensory means used by the yachak shaman to make up for the lack of visibility of the beings summoned on the stage of the ritual performances: spirits, demons, animals or hybrid entities? What are the tools anthropology can use to study this contagion of images among participants? How to define the sensory apparatus affecting the field of representation and beliefs surrounding the ritual? This contribution adopts a new perspective on the notions developed by Lévi-Strauss with regards to the effectiveness of symbols and pragmatic approach to the Amazonian shamanic rituals. It allows us to examine the assumption that it is precisely, in this context, the deficient dimension of the sign - the transgression of the rules of ordinary communication and the partial characteristic of deciphering - that gives the image all its power. The Western paradigm of communication, defined by language sciences in terms of signifying intention or relevance, is here replaced by a pragmatic model based on the multiplication of voices, points of view and possible interpretations of the image.

\section{INDEX}

Keywords: Amazon, effectiveness of symbols, Lévi-Strauss, pragmatics, ritual communication, sensoriality, shamanism

\section{AUTHOR}

\section{ANDREA-LUZ GUTIERREZ CHOQUEVILCA}

Since 2012, Andrea-Luz Gutierrez Choquevilca holds the chair of South-American Indian Religions: Lowland societies at the École Pratique des Hautes Études. She is also senior lecturer of the $\mathrm{V}^{\text {th }}$ section of Religious Sciences (EPHE), a member of the Laboratory of Social Anthropology (UMR 7130 Collège de France) and affiliated to the Laboratory of Comparative Ethnology and Sociology (UPO Nanterre). Her researches are based on a comparative ethnography of lowland Amerindian societies, especially the Peruvian Runa and Achuar. They focus on the religious fact and cultural transmission from a new perspective, combining methods of linguistic anthropology and pragmatics, interactional approach and ecology. Her publications deal with ritual communication, memory systems and relations between orality and writing, the sociology of the interactions between humans and non-humans and the ethnography of the ways to learn and share knowledge in Amerindian traditions. She codirects with Pierre Déléage, the Linguistic Anthropology team at the Laboratory of social anthropology, which gathers anthropologists, sociologists, historians and linguists who explore these topics. 